\title{
外部被曝管理
}

\author{
西 川喜 之*1, 平 沢 悠 紀*1
}

\section{Radiation Protection for Occupational External Exposure}

\author{
Yoshiyuki NishikAwA and Yuuki HiRASAWA*1
}

\section{1. 管理の歴史的概観}

(1)外部被曝管理をモニタリングと防護・管理に大別 し，本稿では防護・管理について述べることとする。

X線やラジウムなどを扱っていたころの防護・管理 は, 放射線障害の発生を防止することを目的とし, 障害 の発生の有無を健康診断によって判断することであっ た。このときの「許容線量」に対する認識は「そこまで の被曝は許され受け容れられるもの」であった。当初の $\mathrm{X}$ 線発生装置や放射線照射用具などの遮蔽の不備はさほ ど問題にされなかったし，取扱いに伴ら被曝もあまり問 題にならなかった。したがって, 防護・管理の仕事は 「許容線量」を超えないようにモニタリングをすること と障害発生の発見のための健康診断を実施することが主 であった。その後，核分裂の利用から出発した原子力開 発の分野では, 開発の初めから放射線の被曝による影響 を懸念していた。その影響を継続的に定性的・定量的に 計りつつ“より少い被曝で”といら視点から防護・管理 を行ってきた。このことはICRP の勧告の中できわめて 重要な役割を果すことになる。

(2)ICRP の勧告が出され，それまであまり明確でなか った防護・管理の概念が, “as low as possible” と具体 的に示された。これによって許容線量内といえども可能 な範囲で被曝線量を引下げるような防護・管理を行らこ とが定着することになった。以前の放射線障害防止の目 的は前提条件に変って来た。このことは現在の “as low as reasonably achievable” に至るまでに, “possible”

*1 日本原子力発電株式会社; 東京都千代田区大手町 1-61 ( $\boldsymbol{T}$ 100)

The Japan Atomic Power Company; 6-1, Ohtemachi 1-chome, Chiyoda-ku, Tokyo 100. $\rightarrow$ "practicable" $\rightarrow$ "readily achievable" $\rightarrow$ "reasonably achievable” と変ったものの “as low as...” という基 本的概念は変っていない。また，低レベル放射線被曝に よる人体への影響についての知見がさらに深まるにつれ て線量限度内の被曝線量では個人のレベルの放射線障害 を臨床的に特定できないことがわかってきたことから， 健康診断による防護・管理の担保の意味がなくなった。 したがって, 防護・管理は許容線量内で種々の管理基準 を設け，基準に応じた防護・管理の具体的方法を定め， これを確実に実行することと，これを確認するモニタリ ングを行らことが防護・管理のお女な仕事になった。健 康診断は日常の健康管理を行うといら広い視点から定期 的に検査することに意味があるとされるようになった。 外部被曝管理の研究・開発は, 正確なモニタリングが主 テーマで進められた。被曝管理対象者が原子力の専門家 や放射線の影響についての知識を持っている人達から， 大規模施設である原子力発電所などでは一般の産業等に 従事する人々まで拡がり, その数も多数になって職業上 被曝する者の範囲が広くなった。個人個人は管理基準を 守ることなどによって許容線量を超えることはないが， 総被曝線量（人・レム）の増加率が大きくなった。この ような状況の変化に対応する防護・管理の方法に種々の 工夫が加えられていった。

(3)ICRP はそれまでの考え方を整理して，1977 年に正 当化, 最適化, 線量制限の三本を主柱とした勧告を出し た。この勧告には一部の專門家の研究領域に限られてい た「リスク」を定量的な道標とし, 大胆な単純化がなさ れている。防護・管理では年線量限度の $3 / 10$ 以下では 個人モニタリングを，また，1/10 以下では記録も必要と しないなど，軽微な部分を明確に区分している。また， 
被曝限度を守るための種々の労働条件の制限や短期間の 限度の廃止など防護・管理の実施にあたり管理者の裁量 を大幅に許したものになっている。な拉，正当化につい ては, 放射線作業が早くから許可や事前届出のシステム をとっていたことからこの許可等手続の中で「なぜこの 作業が必要か」を問らことが日常的に行われており, 特 に新しいシステムが導入されたとは考えられない。

\section{2. 管理手法一1 被曝防護の三原則と被曝低減対策}

防護・管理の考え方の変遷を見て来たが次に具体的な 管理について見てみる。

(1) X線や密封線源の取扱いについての防護・管理は, 防護の三原則

(1)被曝線源と人体との間の遮蔽の設置

(2)被曝線源と人体との距離の延長

(3)被曝時間の短縮

を実行すれば実効があがる。

この三原則をどこまで実行するのが合理的か，また実 際にどれだけ実行すべきかは, 遮蔽について一部法令に は一定線量率で設置するよう定められている他は, 一般 則もなく防護・管理する者の判断に委ねられていた。

(2)原子力開発の発展に伴って，それまでX線や線源を 扱うこと自体が作業であったものが一般的な作業を実施 することに伴って被曝するといら形態に変ってきた。原 子力発電所のような大型原子力施設では, 作業に伴って 被曝する者が原子力の専門家や放射線の技能者でなくな った。

このことから三原則の見直の結果, いわゆる「被曝低 減対策」といわれるものが考え出され実行されて来た。 これは三原則が被曝線源と人との存在, 即ち, 被曝する ことを前提にしているのに対して, 線源あるいは被曝そ のものの存在を根本的に問い質す立場に立った防護・管 理である。これは最初から線源と被曝を是認するのでは なくて「被曝低減対策」を経済的，社会的に許される範 囲内で実行する。その後，更に三原則に適用するもので ある。この被曝低減対策について原子力発電所を例にし て述べる。

(1)被曝線源の発生の防止/低減

利用する線源（たとえば核燃料や核分裂生成物など） の閉じ込めや誘導放射能となる鉄材等の原材料の持込の 防止や低減させる対策である。

(2)被曝線源の作業現場への移行の防止/低減

核分裂生成物や誘導放射能などの被曝線源が作業者の 作業対象物や作業現場近辺に出て来ることを防止する。 あるいは低減させる対策である。

(3)作業現場に存在する被曝線源の除去/低減
(1)，(2)の対策を実施してもなお，作業対象物や作業現 場に存在する被曝線源をフラッシングやパージング等の 方法により取除くか低減させる対策である。また，作業 着手前の機器の水洗や手掃きによる除染などもこの対策 の一部である。

(4)保守・点検作業の不必要化 (Maintenance-free), 作業の機械化による人為作業の肩替り, および保守, 点 検の作業量の低減

人による作業を行わないという立場から, 保守・点検 を必要としない機器類の使用, 必要な保守・点検の口ボ ット化, 工業用テレビの活用, 各種センサによる実施 を, さらに, 保守・点検の間隔の延長・点検頻度の低減 を行らことである。

これらの対策は機器の信頼性の確保と安全・安定運転 の継続という視点から, 正当化と最適化を厳しく吟味し 適用されなければならない。これらの対策は個々に独立 したものではなく, 同時, 併行時に行われるべきもので ある。これらの対策に加えて，

(5)作業手順の改善・改良や工法の工夫あるいは保守・ 点検工具の改良による作業時間の短縮。

(6)工具等の使用による遠距離作業の実施。

(7)作業安全と作業実施を阻害しない範囲での遮蔽の設 置。

など「三原則」の対策が講ぜられる。

この(1)から(7)までのらち(1)〜 (4)を積極的な防護・管理 対策, (5)〜 (7)を消極的対策といらことができる。

\section{3. 管理手法一2 具体的展開}

この被曝低減対策の定着とともにその他の防護・管理 手法の進歩がある。

被曝線源あるいは放射線発生装置を扱うこと自体が作 業で，扱ら者が専門家であったり放射線についてよく知 っている者であった時には，あまり手法を細分したり， 厳密な手順にしておく必要もなかった。原子力開発が進 み原子力発電所のよらな大型原子力施設で一般産業に従 事する人達が多くなるのに伴い防護・管理の手法は誰で も容易に実行でき，それで管理が十分であるような手法 を大幅に取入れて展開された。一般労働安全衛生におけ る作業安全の確保の手法の導入である。

(1)作業の計画と防護・管理計画の立案

(2)作業の必要性の明確化, 作業に伴ら被曝線量の推 定, 被曝低減対策の検討

(3)他作業への影響の波及や干渉などの事前検討および 調整ならびに計画の承認

(4)作業実施の許可（または事前の届け）と被曝低減対 策など作業着手前の準備作業の実施。 
(5)作業着手前の一連の実施事項確認。

66作業中, 手順ど拉り実施していることの確認, 作業 中の作業環境モニタリングの実施, 管理基準を超えない よらにするための監視。

(7)作業後の除染や現状復帰。

8)作業の集約, 被曝線量, 作業線量等の集計と計画 值, 推定值との照合とチェック・アンド・レビュー。

(9)次の作業計画への反映事項のフォロ一。

この手法は, 作業の軽重に応じて, 省略や細分化など が行われ，実行されている。

\section{4. 管理手法-3 管理基準}

放射線作業に従事する者の被曝線量はどのような状況 下にあっても線量限度を超えさせてはならない。管理手 法の中で重要な手法の一つとして「管理基準」の設定と 運用がある。現行法令には年の線量限度はないが ICRP の勧告の年間 5 レムの基準を設定してこれを超えないよ う管理する手法などの代表的なものである。この他管理 基準に作業予定線量がある。これは

(1)一定期間内にあるいは一定期間中の作業単位ごとに (2)作業を完成させるに必要な被曝推定線量を基に

(3)個人個人のそれまでの被曝状態を勘案して

(4)個人ごとに作業終了まであるいは一定期間中の作業 予定線量を設定する。

(5)作業予定線量が一定值を超える場合, 線量の大きさ に応じ管理側の適当な職位の責任者の了解・承認を得 る。

この管理基準は作業の状況や条件が変れば, そのつど 変るもので, 制限や規制といら性格をもったものではな い。基準值は低い值からかなり高い值まで幾段階も設定

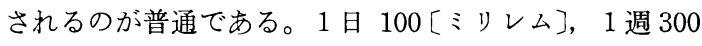
[ミリレム]がよく知られている。管理側の了解・承認 も現場の防護管理者から所長や事業所長などの最高責任 者までレベルと重要さに応じて段階的に定められ，緻密 な管理手法として活用されている。この管理基準の設定 と運用は, 当初, かなり粗く, 事務的なものであったが 大規模原子力施設の増加に伴って様々の工夫がなされ実 効をあげている。

\section{5. 管理手法一 4 被曝監視}

外部被曝防護・管理のうち, 日々の被曝線量の監視 は, ポケットチェンバー（ポケット電離箱）によって行 らことから始った。ポケットチェンバーの充電・読取り を毎日，定時に一本一本管理側で行らシステムであっ
た。大型施設である原子力発電所では，さらに本人がい つでもその時点での被曝線量を知ることの必要性が加わ り，多数のポケット線量計（ポケットドジメータ）を 用いたシステムが運用に入った。その後熱螢光線量計 (TLD) の研究開発に伴って, 管理区域立入管理装置と 組合わせた自動熱螢光線量計, 立入管理装置に EDPS (Electrical Data Processing System) を付けた管理シ ステムが構築されていった。また，設定した管理基準を 超えないよう監視し, 告知するため, 被曝線量が設定值 を超えると視覚的警報と聴覚的警報を出すアラームメー タの開発が早くから進められた。当初は電離箱を用いた 設定值が連続可変のものであったが種々の改良が進めら れ, 本人が線量を読取ることができ, 設定もより正確 にできるアラームドジメータが作業員に幅広く用いら れ, 大規模に活用されている。被曝監視のための測定器 は，手間暇をかけずに使用でき，苛酷な使用に耐え，着 用・取扱いの負担を感ずることなく取扱いやすいもので なければならない。

X線や $\gamma$ 線のほか中性子線などが混在する場合には， $\mathrm{X}$ 線, $r$ 線の線量を指標とする管理が行れ，有効に機能 している。

\section{6. 管理手法一5 線量評価}

個人個人の放射線被曝を[レム]単位で正確に求めて おくことは個人管理業務の中で重要な仕事である。個人 が一定期間，身体に装着していた測定器からの情報を基 に, [レム〕単位で被曝線量を求めるプロセスが「線量 評価」である。線量評価は,フィルムバッジを主体に研 究開発が進められ, 主として線量限度との対比をするた めの值として求められて来た。

これからは，確率的影響や非確率的影響への寄与分を 算出し, それぞれの限度と対比することが求められてゆ くと考えられる。測定器や評価方法は多くの研究・開発 が行われ, 現在, 種々の測定器が用いられ, 様々の評価 方法が用いられている。線量評価の手順が複雑で正確に 求めることの困難さが比較的早い時期に認識され，第三 者機関に依頼することが一般的になっている。

外部被曝線量評価の中では, 器官や臓器の被曝線量の 測定, $\beta$ 線の手指や皮ふの被曝線量測定, 熱中性子線か ら速中性子線まで広範囲のエネルギー幅をもつ場合の中 性子線の被曝線量の正確な測定・高エネルギーの $\gamma$ 線や 電子線の测定など，测定上の問題や [レム]の定義その ものに係る問題などまだまだ研究・開発の課題が多い。 